\title{
Social learning through social networks and technological appropriation: the role of peer effects in the adoption and use of the internet in Cameroonian tontines
}

\author{
Georges D. MBONDO \\ Department of Public Economics, University of Douala, Groupe de Recherche en Economie Théorique et Appliquée, Douala Cameroon
}

Email address:

georges.mbondo@yahoo.com, georgesd.mbondo@gmail.com

\section{To cite this article:}

Georges D. MBONDO. Social Learning through Social Networks and Technological Appropriation: The Role of Peer Effects in the Adoption and Use of the Internet in Cameroonian Tontines. International Journal of Economic Behavior and Organization. Vol. 1, No. 5, 2013, pp. 39-49. doi: 10.11648/j.ijebo.20130105.11

\begin{abstract}
This article attempts to verify whether tontines constitute a social learning platform for the appropriation of technology that underlies patterns of adoption and use of the Internet in sub-Saharan Africa. It uses for this purpose a survey of 2650 households in the cities of Douala, Buea and Limbe and employs initially two zero-inflated count data models to highlight the Intensity of the practice of tontines and after, simple probit models to detect the presence of favorable peer effects in the association tontines on the likelihood of adoption and use of the Internet in Cameroonian households. The results show that, while in ROSCA-type tontines social learning is uncertain because of neutral peer effects, in association tontines within socio-professional groups peer effects are positive and reinforce the process of adoption. These results confirm the studies on dissocializing Internet carried in United States and Europe at the beginning of the dynamics of its diffusion. However and more important, the results presented here show that peer effects play positively on social learning and technology appropriation that underlie the adoption and use of the Internet not in tontine of ROSCA-type, but in the tontine envisaged in professional groups according to their propensity to use modern values for jobs.
\end{abstract}

Keywords: Social Learning, Technology Adoption, Peer Effects, Count Data Models, Internet, Sub-Saharan Africa, Probit Models

\section{Introduction}

The analysis of the phenomenon of social learning in order to understand technological appropriation in southern countries made use of Rotating Savings and Credit Associations (ROSCA) to examine the issue of diffusion/appropriation of innovative agricultural and contraceptive technologies. This analysis put to evidence at least two interactive phenomena with social interaction effects, also known as peer effects, being central. The first concerns the fact that social networks and the social capital that it builds favors mimicking and the diffusion of signals that reduce uncertainty on the benefits of a given technology (Bandiera and Rasul 2006, Rosenzweig 2010, Conley and Udry 2010). The second concerns the status of tontines as closed clubs in which a set of social bonds are build giving the possibility to obtain micro-credit and insurance necessary for the acquisition of the technology
(Rosenzweig 2010, Conley and Udry 2010). Can this framework also favor social learning and technological appropriation that underlie behaviors of adoption and use of the internet in Sub-Saharan African countries?

The question as formulated requires certain clarifications before any investigations of social learning and technological appropriation in the framework of the tontine. Firstly, the concept of ROSCA-type tontine seems too large and ignorant of the variety of social underpinnings of this phenomenon in Sub-Saharan Africa. In fact, it is observed that when the tontine is organized between peasant groups of women, laborers or any other socio-professional category or enterprise, they become communities in which weak ties that generate important externalities and social interactions are built (Granovetter 2000, Conley and Udry 2010, Foster and Rosenzweig 1995, and Munshi 2004). The nature of these externalities and interactions differentiate the tontine into socio-professional categories and allows a 
more detailed refining of the ROSCA-type tontine framework into association tontines according to different socio-professional groups. Secondly, internet technology requires basic training in computer which is not the case with agricultural and contraceptive practices. As such, the role of peer effects (Manski 1993), which is positive as concerns agricultural technologies (Isham J., 2002; Etang, Fieldding and Knowles, 2007) and contraception (Oster and Thornton 2009) is likely to be different for the internet.

However, a rigorous investigation of the role of peer effects in the process of social learning and technological appropriation that underlies behaviors of adoption and use of the internet seems necessary. In fact, though Griliches (1957), while exploring the determinants of decisions of adoption of new technologies emphasized productivity differences, many economists and sociologists have shown that social factors are even more important (Brandner and Strauss, 1959; Havens and Rogers, 1961). It is found that social learning which generates knowledge is a crucial factor of tecnological diffusion (Rogers 1995) and a source of endogenous growth (Romer (1986), Lucas (1988), Aghion et Howitt (1998)), or simply of growth and urbanization (Marshall 1890, Jacobs 1969, Porter 1990, Glaeser and al. 1992, Rauch 1993, Barro and Sala-i-Martin 1994).

In this perspective, the tontine leads one to suppose that a social neighborhood made up of internet users favors social learning and positively affects the likelihood of using the internet in conformity with results already obtained in France and Luxembourg (Pénard and Poussing 2006, Pénard, Suire, Poussing 2011). But, they can also be considered as places of physical socialization, thus, can facilitate the transmission of signals which discourage the use of the internet because of its technological specificity ${ }^{1}$. In this framework, a study through direct survey can provide an early approximation of such effects without however solving the problem of unobserved correlates put to evidence by Manski (1993) and that a large stream of econometric studies have tried to solve during the last two decades (Foster et Rosenzweig, 1995; Conley et Udry 2008; Munshi 2003; Figlio 2003; Bandiera et Rasul 2006; Sacerdote 2000; Kremer et Levy 2006).

The objective of the present study is to verify, on the one hand, if the ROSCA-type tontine constitutes a learning framework for the appropriation of internet technology as established in the literature on agricultural technologies and contraceptives in developing countries. On the other hand, it tries to fine-tune the analysis by putting to evidence the impact of association tontines on the behavior of adoption and use of the internet in households in Cameroon while emphasizing the role of peer effects. To this effect, it uses a survey of 2650 households of the towns of Douala, Buea and Limbe in 2008 and employs two zero-inflated count

\footnotetext{
${ }^{1}$ Contrary to agricultural technologies or contraception which are less regarding as concerns basic training, the use of the internet requires minimum computer knowledge.
}

data models to analyze the effects of various socioeconomic characteristics on the probability of adoption and use of the internet and a simple probit model to detect the presence of favorable peer effects in the association tontine. This completes and extends many studies, on the process of adoption and use of ICTs, in which the role of social interactions remain subsidiary (Mukoko 2012, Tamokwe 2012).

The rest of the article is organized as follows: section 2 deals with the data of the survey and informs on peer effects as concerns social learning and technological appropriation in the tontine; section 3 presents hypotheses on the behavior of adoption and use of the internet as well as the methodology; in section 4 , the results are presented and discussed and section 5 concludes.

\section{Data Survey and Information on Peer Effects as Concerns Social Learning and Technological Appropriation in the Tontine in Cameroon}

The data used is from a survey carried out on a sample of 2650 households distributed in the towns of Limbe, Buea and Douala in Cameroon in 2008. The first two are essentially Anglophone meanwhile the last is more Francophone. The three therefore represent a sociocultural diversity that is important to be considered as cultural origins of behaviors of adoption and use of technologies are relevant in the analysis of ICT appropriation (Mukoko 2012). In particular as associative awareness such as the tontine constitute a panacea in Sub-Saharan Africa; it is however differently perceived in sociological entities that live in the towns above mentioned.

The objective of this section is therefore to highlight this importance of the practice of the tontine to put to evidence the way the questionnaire on the diffusion of ICT in Cameroonian households tries to capture peer effects that are favorable or not to the adoption and use of the internet. To achieve this, the two paragraphs that follow first expose the method of sampling and the information content of the questionnaire before presenting some cross-tabulations susceptible to inform on social interaction effects in the tontine.

\subsection{Sampling Frame, Sampling Method and Information Contained in the Questionnaire}

In the absence of a sampling frame that allows the use of random sampling methods, the itinerary method was adopted. This method has an element of randomness as the itineraries that the surveyors follow are determined randomly. Using cartographic data of the third General Population and Household census of 2005, practically entirely used in the last Cameroon Household Survey (CHS 3) of 2007 that covered the whole territory of Cameroon, survey strata were determined. Constraints of precision, 
cost and representativeness led us to randomly and proportionally select and retain about a hundred counting zones in the 5 subdivisions of the town of Douala. In each stratum, we retained exactly the same number of households as in CHS 3, i.e. on average 12 for Douala. The same procedure was used in the subdivisions of Limbe1, Limbe2, Limbe3 and Buea. As such, the sample retained can be considered representative.

As concerns the administered questionnaire, it is made up of three sections that can inform on the modes and capacities of individual and collective adoption of ICTs by households. The first section treats of the individual characteristics of the respondents. It should however be noted that we keep in mind the possibility that the first person met during the administration of the questionnaire might not be the head of the family and thus will not be able to sufficiently inform on the wealth situation and global behavior of the household. We believe that the respondent can however provide interesting information on individual behaviors in the households. Responses concerning the household are validated when given by the household head. In a general manner and in Sub-Saharan Africa in particular, households are represented by their heads who is generally a man, except in single-parent families. In other words, some households had two respondents when the first person met was not the household head.

The second section of the questionnaire concerns the socio-demographic and economic characteristics of the household. It is here that we have associative life and tontine activities of the respondent in particular. The questionnaire does not distinguish between the types of tontines and does not inform on the internal organization of these tontines. But we know from direct observation that tontines are practically social institutions of solidarity in all Cameroonian communities (Pilon, Locoh, Vignikin, Vimard 1997).

The third section deals with ICT devices and their uses such as mobile phones, computers and the internet. Internet issues considered attempts to cover essential activities necessary to appreciate the appropriation of this technology. In fact, it covers all activities starting from what made the respondent to use the internet the first time to various activities of counseling on access points, access providers, uses, and on frequency of use, passing through, the possibility of using the internet without assistance or not (V119). The response rate gave a sample that was statistically significant for the analysis of the various issues.

\subsection{Pertinent Descriptive Statistics and Cross-Tabulations of Variables for the Analysis of Behaviors of Adoption and Use of the Internet}

Table 1: Relative frequencies of responses concerning the practice of internet activities

\begin{tabular}{|c|c|c|c|c|c|c|c|}
\hline \multicolumn{2}{|c|}{ Internet activities } & $\begin{array}{l}\text { Counsel on the } \\
\text { uses of the } \\
\text { internet } \\
\text { VV127 }\end{array}$ & $\begin{array}{l}\text { Counsel on the } \\
\text { choice of an } \\
\text { access point } \\
\text { VV128 }\end{array}$ & $\begin{array}{l}\text { Counsel on the } \\
\text { choice of an } \\
\text { access } \\
\text { provider } \\
\text { VV129 }\end{array}$ & $\begin{array}{l}\text { Self or assisted } \\
\text { utilization of } \\
\text { the internet } \\
\text { VV119 }\end{array}$ & $\begin{array}{l}\text { Used the } \\
\text { internet } \\
\text { during the last } \\
\text { three months } \\
\text { VV130 }\end{array}$ & $\begin{array}{l}\text { Use of the } \\
\text { internet } \\
\text { everywhere } \\
\text { VV131 }\end{array}$ \\
\hline \multirow{8}{*}{ CSP } & Csp1 & $7,2 \%$ & $6,33 \%$ & $0,94 \%$ & $4,09 \%$ & $6,78 \%$ & $10,35 \%$ \\
\hline & Csp2 & $17,35 \%$ & $14,08 \%$ & $1,88 \%$ & $11 \%$ & $21,42 \%$ & $29,37 \%$ \\
\hline & Csp3 & $11,48 \%$ & $8,09 \%$ & $3,40 \%$ & $5,57 \%$ & $13,21 \%$ & $20,52 \%$ \\
\hline & Csp4 & $8,55 \%$ & $5,98 \%$ & $0,94 \%$ & $5,85 \%$ & $10,36 \%$ & $13,75 \%$ \\
\hline & Csp5 & $4,92 \%$ & $0,92 \%$ & $1,74 \%$ & $4,96 \%$ & $11,13 \%$ & $13,95 \%$ \\
\hline & Csp6 & $1,27 \%$ & $4,27 \%$ & $1,29 \%$ & $3,36 \%$ & $7,38 \%$ & $10,92 \%$ \\
\hline & Csp7 & $4,04 \%$ & $6,04 \%$ & $3,16 \%$ & $2,72 \%$ & $4,54 \%$ & $8,41 \%$ \\
\hline & Csp8 & $3,11 \%$ & $3,1 \%$ & $1,11 \%$ & $3,88 \%$ & $2,78 \%$ & $5,77 \%$ \\
\hline \multirow{3}{*}{ Income level } & Rev1 & $16,31 \%$ & $14,22 \%$ & $2 \%$ & $10,78 \%$ & $19,97 \%$ & $27,03 \%$ \\
\hline & Rev2 & $27,71 \%$ & $15,63 \%$ & $2 \%$ & $13,01 \%$ & $22,23 \%$ & $31,57 \%$ \\
\hline & Rev3 & $19,01 \%$ & $12,22 \%$ & $5,41 \%$ & $9,60 \%$ & $21,40 \%$ & $32,70 \%$ \\
\hline \multirow{5}{*}{ Age group } & Age1 & $10,48 \%$ & $7,03 \%$ & $0,28 \%$ & $6,26 \%$ & $10,28 \%$ & $13,99 \%$ \\
\hline & Age2 & $21,54 \%$ & $17,99 \%$ & $5,35 \%$ & $12,88 \%$ & $25,35 \%$ & $36,57 \%$ \\
\hline & Age3 & $17,28 \%$ & $10,73 \%$ & $7,40 \%$ & $9,21 \%$ & $17,40 \%$ & $24,25 \%$ \\
\hline & Age4 & $9,21 \%$ & $5,53 \%$ & $0,16 \%$ & $4,99 \%$ & $10,16 \%$ & $16,41 \%$ \\
\hline & Age 5 & $0,46 \%$ & $0,23 \%$ & $0,11 \%$ & $0,27 \%$ & $0,11 \%$ & $0,18 \%$ \\
\hline \multirow{5}{*}{$\begin{array}{l}\text { Level of } \\
\text { education }\end{array}$} & Educ1 & $1,27 \%$ & $0,46 \%$ & - & $0,94 \%$ & $0,81 \%$ & $0,92 \%$ \\
\hline & Educ2 & $6,68 \%$ & $5,07 \%$ & $0,92 \%$ & $6,08 \%$ & $7,71 \%$ & $10,59 \%$ \\
\hline & Educ3 & $16,36 \%$ & $13,49 \%$ & $1,27 \%$ & $11,05 \%$ & $17,99 \%$ & $24,16 \%$ \\
\hline & Educ4 & $16,60 \%$ & $11,08 \%$ & $4,04 \%$ & $9 \%$ & $19,62 \%$ & $28,43 \%$ \\
\hline & Educ5 & $15,90 \%$ & $11,07 \%$ & $3,11 \%$ & $7,22 \%$ & $17,29 \%$ & $27,32 \%$ \\
\hline
\end{tabular}

Source: Author's construction

The cross-tabulations are shown in tables 2 and 3 below; in table 2 as concerns the relationships between socioeconomic characteristics and the practice of activities linked to the internet and table 3 for the relationship 
between the tontine and these same activities. Table 2 reveals that in general, less than $20 \%$ of respondents had access to counseling activities whether for the uses of the internet, for access points or for access providers. We also notice that only professional categories of intermediary professions and senior manager have scores greater than $10 \%$. Meanwhile by observing the age structure, we notice that the highest frequency of advices for the choice of cybercafés is for individual aged between 15 and 21 years and the highest frequency for the choice of access providers is for senior managers. It is however impressive that the proportion of those who perform these various activities and who are members of at least one tontine is low no matter the socio-professional category, the age group or income. This low level of the presence of individuals who practice the internet through any means prefigures the nature of the effects of peers or masters in tontines. Finally, a particular remark: though the proportion of men who use the internet remains higher than that of women, the difference is not very important such that the lack of the appropriation of internet technology in Cameroonian tontines cannot be imputed to gender. These observations comfort the opinion which consists of studying if tontines constitute a social learning milieu for the appropriation of internet technology.

Associating the tontine and socio-professional categories, they appear to be veritable social learning milieus and not only ROSCAs. Association tontines happen to be communities of interpersonal relationships which base collective action on confidence in financial, social and work solidarities between the members. As such, they are more of village (village or ethnic groups) or urban (proximity bonds between people from different ethnic groups and living in towns) but differentiate themselves by informational externalities produced by objectives centered on the transmission and sharing of knowledge at the work place and on daily life in general.

Table 2: Relative frequencies concerning the practice of internet activities by members of at least one tontine

\begin{tabular}{|c|c|c|c|c|c|c|c|}
\hline \multicolumn{2}{|c|}{ Internet activities } & $\begin{array}{l}\text { Counsel on the } \\
\text { uses of the } \\
\text { internet } \\
\text { VV127 }\end{array}$ & $\begin{array}{l}\text { Counsel on the } \\
\text { choice of an } \\
\text { access point } \\
\text { VV128 }\end{array}$ & $\begin{array}{l}\text { Counsel on the } \\
\text { choice of an } \\
\text { access } \\
\text { provider } \\
\text { VV129 }\end{array}$ & $\begin{array}{l}\text { Self or assisted } \\
\text { utilization of } \\
\text { the internet } \\
\text { VV119 }\end{array}$ & $\begin{array}{l}\text { Used the } \\
\text { internet } \\
\text { during the last } \\
\text { three months } \\
\text { VV130 }\end{array}$ & $\begin{array}{l}\text { Use of the } \\
\text { internet } \\
\text { everywhere } \\
\text { VV131 }\end{array}$ \\
\hline \multirow{8}{*}{ CSP } & Csp1t & $1,72 \%$ & $1,37 \%$ & $0,22 \%$ & $1,26 \%$ & $1,39 \%$ & $2,22 \%$ \\
\hline & Csp2t & $1,14 \%$ & $1,26 \%$ & $0,11 \%$ & $0,61 \%$ & $1,27 \%$ & $2,03 \%$ \\
\hline & Csp3t & $0,11 \%$ & $0,11 \%$ & 0 & $0,04 \%$ & $0,11 \%$ & $0,18 \%$ \\
\hline & Csp4t & $2,63 \%$ & $1,49 \%$ & $0,34 \%$ & $1,53 \%$ & $2,67 \%$ & $3,88 \%$ \\
\hline & Csp5t & $8,36 \%$ & $5,96 \%$ & $2,87 \%$ & $3,91 \%$ & $9,05 \%$ & $14,44 \%$ \\
\hline & Csp6t & $4,92 \%$ & $2,98 \%$ & $1,15 \%$ & $2,26 \%$ & $4,99 \%$ & $7,40 \%$ \\
\hline & Csp7t & $0,57 \%$ & $0,57 \%$ & $0,22 \%$ & $0,42 \%$ & $0,69 \%$ & $0,92 \%$ \\
\hline & Csp8t & $5,73 \%$ & $3,90 \%$ & $0,57 \%$ & $3,48 \%$ & $6,85 \%$ & $8,70 \%$ \\
\hline \multirow{3}{*}{ Income level } & Rev1t & $1,37 \%$ & $1,37 \%$ & $0,11 \%$ & $1,07 \%$ & $1,51 \%$ & $2,03 \%$ \\
\hline & Rev2t & $11,11 \%$ & $7,56 \%$ & $1,26 \%$ & $6,06 \%$ & $11,61 \%$ & $16,11 \%$ \\
\hline & Rev3t & $12,60 \%$ & $8,6 \%$ & $3,90 \%$ & $6,55 \%$ & $14,05 \%$ & $21,48 \%$ \\
\hline \multirow{5}{*}{ Age group } & Agelt & $0,34 \%$ & $0,80 \%$ & $0,11 \%$ & $0,38 \%$ & $0,69 \%$ & $1,29 \%$ \\
\hline & Age2t & $6,76 \%$ & $5,38 \%$ & $1,37 \%$ & $3,94 \%$ & $7,78 \%$ & $10,92 \%$ \\
\hline & Age3t & $11,11 \%$ & $6,76 \%$ & $1,83 \%$ & $5,78 \%$ & $11,84 \%$ & $16,11 \%$ \\
\hline & Age4t & $6,75 \%$ & $4,58 \%$ & $2,18 \%$ & $3,60 \%$ & $7,20 \%$ & $11,85 \%$ \\
\hline & Age5t & $0,34 \%$ & $0,22 \%$ & 0 & $0,19 \%$ & $0,11 \%$ & $0,18 \%$ \\
\hline \multirow{5}{*}{$\begin{array}{l}\text { Level of } \\
\text { education }\end{array}$} & Educ1t & $1,26 \%$ & $0,45 \%$ & 0 & $0,92 \%$ & $0,81 \%$ & $0,92 \%$ \\
\hline & Educ2t & $2,63 \%$ & $1,72 \%$ & $0,11 \%$ & $2,37 \%$ & $2,90 \%$ & $4,07 \%$ \\
\hline & Educ3t & $5,49 \%$ & $4,58 \%$ & $0,80 \%$ & $3,37 \%$ & $5,92 \%$ & $7,96 \%$ \\
\hline & Educ4t & $8,23 \%$ & $5,61 \%$ & $2,87 \%$ & $4,02 \%$ & $9,05 \%$ & $13,52 \%$ \\
\hline & Educ5t & $8,82 \%$ & $5,61 \%$ & $1,72 \%$ & $3,79 \%$ & $9,40 \%$ & $14,63 \%$ \\
\hline
\end{tabular}

Source: Author's construction

\section{Hypotheses and Methodology}

The statistical exploration of the data collected from the survey led us to formulate three hypotheses after which the methodology used for testing the hypotheses are elaborated.

\subsection{Hypotheses}

The first hypothesis denoted $\mathrm{H}_{1}$, is that: the tontine is a social institution that has an impact on the decision of households to adopt and use technology. It is characterized by the self-enforcement of its practice and presents itself as a bank of proximity. The second hypothesis, denoted $\mathrm{H}_{2}$, is that: peer effects are uncertain in ROSCA-type tontines as concerns the learning and appropriation of internet technology. This hypothesis attenuates the conclusions of studies on questions of social learning and the appropriation of agricultural technologies and contraceptives.

In fact, it is easily understood that the presence in 
tontines (framework that favors financing, the revelation of benefits, the reduction of learning cost, positive informational externalities, and the improvement of social capital) of members that have adopted and uses the internet reinforces the adoption and use of other members, but can also be hindered by opposite reasons (negative peer effects, gender issues characterizing those who frequently use it). Table 2 shows that internet activities are practically insignificant in households who practice the tontine. Two models are employed to put to evidence two types of externalities in social networks: a direct externality (family members and external friends) and an indirect externality (member of an association or a tontine). The expected signs of the different effects are presented in table 3 below.

Table 3: Expected effects of explanatory variables of ROSCA models

\begin{tabular}{|c|c|c|c|}
\hline $\begin{array}{l}\text { Explanatory } \\
\text { variables }\end{array}$ & $\begin{array}{l}\text { Expected } \\
\text { effects on } \\
\text { tontine } \\
\text { participation }\end{array}$ & $\begin{array}{l}\text { Expected } \\
\text { effects on the } \\
\text { adoption of } \\
\text { the internet }\end{array}$ & $\begin{array}{l}\text { Expected } \\
\text { effects on the } \\
\text { uses of the } \\
\text { internet }\end{array}$ \\
\hline Internet & uncertain & - & Positive \\
\hline Tontine & - & Positive & uncertain \\
\hline tontine2 & - & Positive & uncertain \\
\hline assoc & Positive & Positive & Positive \\
\hline age 2 & Positive & Positive & Positive \\
\hline age 3 & Positive & Positive & Positive \\
\hline age4 & Positive & Neutral & Neutral \\
\hline age 5 & Positive & Neutral & Neutral \\
\hline age6 & Positive & Positive & Positive \\
\hline educ2 & Neutral & Positive & Positive \\
\hline educ3 & Neutral & Positive & Positive \\
\hline educ4 & Neutral & Positive & Positive \\
\hline educ5 & Positive & Neutral & Neutral \\
\hline educ6 & Neutral & Positive & Positive \\
\hline educ7 & Positive & Positive & Positive \\
\hline sex & Positive & Neutral & Neutral \\
\hline abroad & Positive & Positive & Positive \\
\hline scorequip & Positive & neutral & Neutral \\
\hline rev2 & Positive & Neutral & Neutral \\
\hline rev3 & uncertain & positive & Positive \\
\hline rev4 & Positive & positive & Neutral \\
\hline $\operatorname{soc} 2$ & Positive & positive & Neutral \\
\hline soc3 & uncertain & positive & Positive \\
\hline $\begin{array}{l}\text { learnfor } \\
\text { learninfor }\end{array}$ & uncertain & positive & Positive \\
\hline
\end{tabular}

Source: Author's construction

The third hypothesis denoted $\mathrm{H}_{3}$, is that: peer effects are positive in association tontines circumscribed to socioprofessional categories and whose members have training in computer. This hypothesis supposes that tontines do not only act as club of friends where one can obtain credit to finance purchases of a technology, but workers clubs organized among socio-professional categories where informational externalities that can create contact with peers are distilled.

\subsection{Methodology}

In order to test the three hypotheses of the preceding subsection, two types of models are employed. The first is a count data model to sample the nature and intensity of tontine membership and the second, simple probit models to explain the probability of social learning and technological appropriation which underlie behaviors of adoption and use of the internet.

\section{$i$. Count data modeling and tontine participation}

As participation to at least one tontine is a non-negative discrete variable, we can use a count data model. In this regards, two zero expansion count data models are retained. This choice is justified since these models express the fact that if an individual does not participate to a tontine, the dependent variable will always take the value of zero, and meanwhile, if he decides to participate, the dependent variable can take values that follow a distribution that behaves like the poisson or a negative binomial distribution. Traditional count data models are not able to solve this problem which is regular in most survey data. As such, the zero value of non-participation becomes the consequence of two phenomena which can be expressed in two ways:

- In the case of the probability distribution of the zero-inflated Poisson model (ZIP), we have:

$$
\begin{aligned}
& P\left(Y_{i}=0\right)=q_{i}+\left(1-q_{i}\right) e^{-\lambda_{i}} \\
& P\left(Y=y_{i}>0\right)=\left(1-q_{i}\right) \frac{e^{-\lambda_{i}} \lambda_{i}^{y_{i}}}{y_{i} !}
\end{aligned}
$$

- $\quad$ In the case of zero-inflated negative binomial model (ZINB), the probability distribution is expressed as :

$$
\begin{aligned}
& P\left(Y_{i}=0\right)=q_{i}+\left(1-q_{i}\right)\left(\frac{v}{v+\lambda_{i}}\right)^{v} \\
& P\left(Y=y_{i}>0\right)=\left(1-q_{i}\right) \frac{\Gamma\left(y_{i}+v\right)}{\Gamma\left(y_{i}+1\right) \cdot \Gamma(v)} \cdot\left(\frac{v}{v+\lambda_{i}}\right)^{v} \cdot\left(\frac{\lambda_{i}}{v+\lambda_{i}}\right)^{y_{i}}
\end{aligned}
$$

Where $q_{i}$ is the probability is the probability of nonparticipation and $\left(1-q_{i}\right)$ is that of participation. The expected value and variance are given by:

$$
E\left(Y / x_{i}\right)=\left(1-q_{i}\right) \lambda_{i} \text { and } \operatorname{Var}\left(Y / x_{i}\right)=\lambda_{i}\left(1-q_{i}\right)\left(1+\lambda_{i} q_{i}\right)
$$

in the case of the ZIP model, $E\left(Y / x_{i}\right)=\left(1-q_{i}\right) \lambda_{i}$ and $\operatorname{Var}\left(Y / x_{i}\right)=\lambda_{i}\left(1-q_{i}\right)\left(1+\alpha \lambda_{i}+\lambda_{i} q_{i}\right)$ in the case of the ZINB model.

$\alpha$ is the parameter that permits to choose between the Poisson model (ZIP) and the negative binomial model (ZINP). As for the probability $q_{i}$, when it is zero, $q_{i}=0$, we are in the case of the Poisson or negative binomial models as the case may be. Consequently, the test of nullity or not of this parameter helps to decide which of these two models (the zero-inflated or the traditional one) is the best or the most appropriate for the proposed estimation. Unfortunately, computer software do not test this parameter directly, but they consider that it follows a particular distribution. In the 
framework of the Limdep 7.0 software used in this study, $q_{i}$ follows a logistic distribution.

\section{ii. $\quad$ Probit models and peer effects in the tontine}

After haven characterized the intensity of tontine participation in the sample, the next problem is the test of the two last hypotheses on the role of peer effects in social learning and technological appropriation, a phenomenon which underlie the behaviors of adoption and use of new technologies in general and the internet in particular. The choice of probit modeling is justified by the qualitative and dichotomous nature of the data used.

As shown in tables 1 and 2, variables of interest here express learning and appropriation on the one hand, and motivation and neighborhood influence on the other. They are each designated by $\mathrm{y}$ in a particular model. We can therefore state that each time, y represents one of the elements of the set of dependent variables, such that we have:

$$
y \in\{v 119, v 127, v 128, v 129, v 130, v 131\}
$$

$\mathrm{Y}$ takes the value of 1 in case of realization and 0 otherwise. It is therefore a dichotomous variable. This can be written as:

$$
Y_{i}=\left\{\begin{array}{l}
1 \text { if the answer of the respondent is affirmative } \\
0 \text { if the answer of the respondent is negative }
\end{array}\right.
$$

Elsewhere, the status of $y$ is determined by a set of explanatory variables found once more in tables 1 and 2 .

$$
Y_{i}=\Phi\left(\alpha+\beta X_{i}\right)+\varepsilon_{i}
$$

Where $\Phi(\ldots)$ is an application, whose values are necessarily found in the interval 0 to 1 . The choice of a probit model means that $\Phi(\ldots)$ follows a normal distribution function such that we have:

$$
\Phi\left(\alpha+\beta X_{i}\right)=\int_{-\infty}^{\alpha+\beta X_{i}} \frac{1}{\sqrt{2 \pi}} \exp \left(-\frac{z^{2}}{2}\right) d z
$$

As such we have:

$$
P\left(Y_{i}=1\right)=\operatorname{Pr} o b\left(X_{i} \beta+\varepsilon_{i}>\gamma\right)=\operatorname{Pr} o b\left(\varepsilon_{i}>\gamma-X_{i} \beta\right)
$$

and:

$$
P(Y=0)=\operatorname{Pr} o b\left(X_{i} \beta+\varepsilon_{i}<\gamma\right)=\operatorname{Pr} o b\left(\varepsilon_{i}<\gamma-X_{i} \beta\right)
$$

\begin{tabular}{|c|c|c|c|c|c|c|}
\hline \multirow{2}{*}{ Tontine } & \multicolumn{3}{|c|}{ Regression estimation of zero-inflated poisson } & \multicolumn{3}{|c|}{ Zero-inflated Negative binomial regression estimation } \\
\hline & Coef. & $\mathbf{z}$ & $\mathbf{P}>|z|$ & Coef. & $\mathbf{z}$ & $\mathbf{P}>|\mathbf{z}|$ \\
\hline Internet & -.1789008 & -2.63 & 0.008 & -.1788869 & -2.63 & 0.008 \\
\hline rev1 & .3349354 & 0.40 & 0.688 & 3349338 & 0.40 & 0.688 \\
\hline rev2 & .5556499 & 0.67 & 0.504 & .555635 & 0.67 & 0.504 \\
\hline rev3 & .7168571 & 0.86 & 0.388 & .7168238 & 0.86 & 0.388 \\
\hline $\operatorname{sex}$ & -.2399568 & -4.77 & 0.000 & -.2399406 & -4.77 & 0.000 \\
\hline abroad & .2549714 & 4.87 & 0.000 & .2549578 & 4.87 & 0.000 \\
\hline scorequip & .0479189 & .2 .72 & 0.007 & .0479147 & .2 .72 & 0.007 \\
\hline educ1 & .4629405 & 1.94 & 0.052 & .462882 & 1.94 & 0.052 \\
\hline educ2 & .4698047 & 2.01 & 0.045 & .469746 & 2.01 & 0.045 \\
\hline educ3 & .4257439 & 1.80 & 0.072 & .4256901 & 1.80 & 0.072 \\
\hline educ4 & .3204374 & 1.31 & 0.192 & .3203903 & 1.31 & 0.192 \\
\hline educ5 & .192582 & 0.76 & 0.445 & .1925401 & 0.76 & 0.446 \\
\hline educ6 & .3034174 & 1.24 & 0.214 & .3033732 & 1.24 & 0.214 \\
\hline age1 & -1.721013 & -8.34 & 0.000 & -1.72096 & -8.34 & 0.000 \\
\hline age2 & -.4135739 & -3.07 & 0.002 & -.413549 & -3.07 & 0.002 \\
\hline age3 & .2173754 & 1.75 & 0.080 & .2173626 & 1.75 & 0.080 \\
\hline age4 & 2530851 & 2.05 & 0.041 & .2530692 & 2.05 & 0.041 \\
\hline age6 & .1736378 & 0.72 & 0.469 & 1736261 & 0.72 & 0.469 \\
\hline assoc & .172541 & 4.77 & 0.000 & .1725366 & 4.77 & 0.000 \\
\hline cons & -1.352472 & -1.61 & 0.106 & -1.352424 & -1.61 & 0.106 \\
\hline \multicolumn{4}{|c|}{$\begin{array}{l}\text { Nber of observations: } 2142 ; \text { Wald chi } 2=440,13 ; \\
\text { Prob }>\text { chi } 2=0,0000 ; \text { Pseudo } R 2=0,1135\end{array}$} & \multicolumn{3}{|c|}{$\begin{array}{l}\text { Number of observations: } 2142 \\
\text { Wald chi } 2=440,8 ; \text { Prob }>\text { chi } 2=0,0000 \\
\text { Log pseudolikelihood }=-2220 \\
\text { Dispersion = mean }\end{array}$} \\
\hline
\end{tabular}

The results presented here are obtained using the Stata 10.0 software. The results are presented in the following section.

Table 4: Regression estimation of the zero-inflated poisson and negative binomial models 


\section{Results and Discussions}

The results obtained using the maximum likelihood estimation technique and presented in the following paragraphs confirm the three hypotheses elaborated. Peer effects reinforce the process of adoption in association tontines, same as it hinders this process in ROSCA-type tontines. These results are presented in detail in tables 5, 6, and 7.

\subsection{The Intensity of Tontine Participation}

Table 5 confirms the theoretical effects expected from the zero-inflated count data models. The positive and insignificant signs of the variables of both the zero-inflated poisson model and the zero-inflated negative binomial model permit the validation of hypothesis $\mathrm{H}_{1}$. Among these variables, we have women of all age groups, education and non-internet equipment scores. Particularly, the positive and significant coefficients of the variable association (assoc) seem also to validate the hypothesis of selfreinforcement of the practice of association in the studied population. On the contrary, all the coefficients of the different income groups are not significant and this makes the factor income a neutral one as concerns participation in tontines. The fact to have already used the internet appears like a negative factor, as if the internet could lead to the destruction of this social practice. As such, these zeroinflated models put to evidence the intensity of participation in tontines among the studied population as well as the detection of favorable, unfavorable and neutral factors in this practice. The consistence and robustness of the results reveal the pertinence of the analysis of the phenomenon of social learning for the appropriation of technology which is at the base of behaviors of adoption of the internet.

Table 5: Results of probit regression and marginal effects

\begin{tabular}{|c|c|c|c|c|c|c|}
\hline \multirow{2}{*}{ Variable } & \multicolumn{3}{|c|}{ Probit regression } & \multicolumn{3}{|c|}{ Marginal effects } \\
\hline & Coef. & $\mathbf{z}$ & $\mathbf{P}>|\mathbf{z}|$ & $d y / d x$ & $\mathbf{z}$ & $\mathbf{P}>|\mathbf{z}|$ \\
\hline Tontine & -.3429216 & -3.58 & 0.000 & -.1114981 & -3.64 & 0.000 \\
\hline Tontine 2 & .0765021 & 3.40 & 0.001 & .024874 & 3.46 & 0.001 \\
\hline assoc & .0295036 & 0.52 & 0.600 & .0095928 & 0.52 & 0.600 \\
\hline age $2 *$ & .4767424 & 3.74 & 0.000 & .1634558 & 3.61 & 0.000 \\
\hline age $3 *$ & .1159542 & 0.86 & 0.389 & .0381777 & 0.85 & 0.394 \\
\hline age $4 *$ & .186162 & 1.13 & 0.259 & .0626948 & 1.09 & 0.275 \\
\hline age $5 *$ & -.4142769 & -1.10 & 0.273 & -.1166838 & -1.31 & 0.189 \\
\hline age $6 *$ & -.8789745 & -2.38 & 0.017 & - . 1995965 & -3.98 & 0.000 \\
\hline educ2* & .0659262 & 0.44 & 0.662 & .0215676 & 0.44 & 0.663 \\
\hline educ $3 *$ & .4930818 & 3.24 & 0.001 & .1707232 & 3.15 & 0.002 \\
\hline educ4* & .7411527 & 3.99 & 0.000 & .2746112 & 3.81 & 0.000 \\
\hline educ5* & .6195876 & 2.81 & 0.005 & .2282321 & 2.64 & 0.008 \\
\hline educ6* & 1.35231 & 5.16 & 0.000 & .5004658 & 5.84 & 0.000 \\
\hline educ7* & .7811046 & 2.01 & 0.044 & .2942344 & 1.93 & 0.054 \\
\hline sex* & .1621193 & 1.91 & 0.056 & .0524233 & 1.93 & 0.053 \\
\hline abroad* & .2270094 & 2.59 & 0.010 & .0729529 & 2.65 & 0.008 \\
\hline scoreq p & .0451899 & 1.58 & 0.114 & .0146931 & 1.59 & 0.113 \\
\hline rev2* & -.1185086 & -1.18 & 0.238 & -.0387312 & -1.18 & 0.239 \\
\hline rev3* & .24457229 & 1.84 & 0.065 & .0833478 & 1.77 & 0.077 \\
\hline rev4* & -.0004347 & -0.00 & 0.999 & -.0001413 & -0.00 & 0.999 \\
\hline $\operatorname{soc} 2 *$ & .5362679 & 4.15 & 0.000 & .1815628 & 4.23 & 0.000 \\
\hline $\operatorname{soc} 3 *$ & 1.261815 & 9.57 & 0.000 & .4353605 & 10.42 & 0.000 \\
\hline learnfor* & 1.190104 & 10.69 & 0.000 & .4268991 & 10.58 & 0.000 \\
\hline learni r* & 1.672763 & 12.61 & 0.000 & .5955274 & 15.19 & 0.000 \\
\hline \multicolumn{4}{|c|}{ Number of observations: 1989 ; Wald chi2 $(24)=548,29$; } & \multicolumn{3}{|c|}{$Y=\operatorname{Pr}($ internet $)=0,26121053$} \\
\hline
\end{tabular}

Source: Author's from regression estimations using STATA 10.0

\subsection{Results of the Probit Model in the Explanation of the Role of Peer Effects as Concerns Adoption of the Internet in Cameroon}

The results of the probit model used in order to highlight social learning that underlie behaviors of adoption are presented in table 5 below. The results of the estimation of marginal effects which are necessary for the understanding and interpretation of the coefficients are also presented. The Wald statistics and the pseudo R2 of Mc Fadden reported in 
the last line of the table indicate the global significance of the regression. The probability that the internet be used in a ROSCA-type tontine in which some members are already internet users is 0.261 on average. However, this result hides many situations that need to be highlighted through a more detailed analysis of the results of the table, since it varies according to the different characteristics of the studied population.

The social learning mechanism highlights four phenomena: the level of education and initial computer training, the age (age6) of the future adopter, network informational externalities, and tontine participation. In fact, it seems that education (educ3, educ4, educ5, educ6 and educ7) and computer training (formal (learnfor) and informal (learninfor)) are strong determinants especially if we consider the marginal effects around the mean. Direct externalities of social networks expressed in the form of acquaintances abroad (dummy v43) and communication needs (soc2 and soc3) is strong. More profoundly, we notice the negative effect of the variable tontine on adoption of the internet meanwhile its quadratic term conserves a positive effect. Consequently and all things being equal, the probability of adopting internet technology decreases with tontine participation before rising above a given threshold (U-shaped relationship). This leads us to think that participating in many tontines increases the probability of social learning. But, this also permits to observe that, depending on the characteristics of the structure or its position on the modern social scale of values, tontines can constitute social learning frameworks for the appropriation or not of internet technology. It is in this situation that peer effects acts, thanks to the possibility of meeting other users (positive peer-effect) or, the effect is opposite when few users are met (negative peer effects). This is why the results cannot be extended to all types of tontines.

\subsection{Results Obtained from Association Tontine Models}

Table6 : Estimation results of adoption and use models of households participating in association tontines

\begin{tabular}{|c|c|c|c|c|c|c|c|}
\hline Definition of explanatory variables & variables & V119 & V130 & V129 & V128 & V127 & V131 \\
\hline $\begin{array}{l}\text { Unemployed and member of tontines } \\
\text { Female unemployed and member of } \\
\text { tontines }\end{array}$ & $\begin{array}{l}\text { Cspla } \\
\text { Csp1b }\end{array}$ & $\begin{array}{l}-0.809 \\
(-3.94)^{*} \\
0.292 \\
(2.26)^{*}\end{array}$ & $\begin{array}{l}-0.327 \\
(-0.68) \\
-0.715 \\
(-1.32)\end{array}$ & $\begin{array}{l}-4.99 \\
(-13.52) \\
/\end{array}$ & $\begin{array}{l}-0.0087 \\
(-0.02) \\
-0.250 \\
(-0.47)\end{array}$ & $\begin{array}{l}-0.499 \\
(-1.04) \\
0.0403 \\
(0.08)\end{array}$ & $\begin{array}{l}4.633 \\
(9.87) \\
/\end{array}$ \\
\hline $\begin{array}{l}\text { Student member of Tontines } \\
\text { Female student member of tontines }\end{array}$ & $\begin{array}{l}\text { Csp2a } \\
\text { Csp2b }\end{array}$ & $\begin{array}{l}0.189 \\
(0.36) \\
0.581 \\
(0.99)\end{array}$ & $\begin{array}{l}5.69 \\
(16.63)^{*} \\
-5.674 \\
(\ldots \ldots)\end{array}$ & $\begin{array}{l}-4.982 \\
(-9.86)^{*} \\
4.58 \\
(\ldots . .)\end{array}$ & $\begin{array}{l}0.217 \\
(0.24) \\
0.430 \\
(0.45)\end{array}$ & $\begin{array}{l}-0.277 \\
(-0.31) \\
0.253 \\
(0.27)\end{array}$ & $\begin{array}{l}0.813 \\
(0.52) \\
/\end{array}$ \\
\hline $\begin{array}{l}\text { Craftsman, farmer member of tontines } \\
\text { Craftswoman, female farmer member of } \\
\text { tontines }\end{array}$ & $\begin{array}{l}\text { Csp3a } \\
\text { Csp3b }\end{array}$ & $\begin{array}{l}-0.330 \\
(-6.41)^{*} \\
-1.015 \\
(-2.10)^{*}\end{array}$ & $\begin{array}{l}1 \\
1 \\
1\end{array}$ & $\begin{array}{l}0.379 \\
(3.18)^{*}\end{array}$ & $\begin{array}{l}0.027 \\
(0.44) \\
/\end{array}$ & $\begin{array}{l}0.173 \\
(1.99)^{*}\end{array}$ & $\begin{array}{l}0.104 \\
(0.67) \\
/\end{array}$ \\
\hline $\begin{array}{l}\text { Trader and head of enterprises member of } \\
\text { tontines } \\
\text { Female trader and head of enterprises }\end{array}$ & $\begin{array}{l}\text { Csp4a } \\
\text { Csp4b }\end{array}$ & $\begin{array}{l}-0.153 \\
(-2.15)^{*} \\
0.367 \\
(3.49)^{*}\end{array}$ & $\begin{array}{l}-0.117 \\
(-0.46) \\
-0.427 \\
(-1.00)\end{array}$ & $\begin{array}{l}-0.133 \\
(-0.40) \\
/\end{array}$ & $\begin{array}{l}-0.172 \\
(-0.67) \\
-0.405 \\
(-1.30)\end{array}$ & $\begin{array}{l}-0.238 \\
(-2.95)^{*} \\
0.455 \\
(2.04)^{*}\end{array}$ & $\begin{array}{l}-0.085 \\
(0.53) \\
0.153 \\
(0.31)\end{array}$ \\
\hline $\begin{array}{l}\text { Intellectual cadre member of tontines } \\
\text { female intellectual cadre }\end{array}$ & $\begin{array}{l}\text { Csp5a } \\
\text { Csp5b }\end{array}$ & $\begin{array}{l}1.05 \\
(8.96)^{*} \\
-0.368 \\
(-2.65)^{*}\end{array}$ & $\begin{array}{l}0.593 \\
(3.28)^{*} \\
-0.244 \\
(-0.70)\end{array}$ & $\begin{array}{l}0.663 \\
(3.55)^{*} \\
0.019 \\
(0.06)\end{array}$ & $\begin{array}{l}0.152 \\
(0.96) \\
0.797 \\
(2.38)^{*}\end{array}$ & $\begin{array}{l}0.342 \\
(2.08)^{*} \\
0.331 \\
(0.94)\end{array}$ & $\begin{array}{l}0.572 \\
(1.70) \\
-0.375 \\
(-0.64)\end{array}$ \\
\hline $\begin{array}{l}\text { Intermediary Prof. Member of Tontines } \\
\text { Female intermediary Prof. }\end{array}$ & $\begin{array}{l}\text { Csp6a } \\
\text { Csp6b }\end{array}$ & $\begin{array}{l}0.799 \\
(5.01)^{*} \\
0.703 \\
(2.30)^{*}\end{array}$ & $\begin{array}{l}0.212 \\
(0.91) \\
0.158 \\
(0.43)\end{array}$ & $\begin{array}{l}0.07 \\
(0.26) \\
0.337 \\
(0.86)\end{array}$ & $\begin{array}{l}-0.080 \\
(-0.36) \\
0.396 \\
(2.36)^{*}\end{array}$ & $\begin{array}{l}0.379 \\
(1.62) \\
0.158 \\
(0.43)\end{array}$ & $\begin{array}{l}0.065 \\
(2.40)^{*} \\
4.704 \\
(11.28)^{*}\end{array}$ \\
\hline $\begin{array}{l}\text { Employee member of Tontines } \\
\text { Female employee member of Tontine }\end{array}$ & $\begin{array}{l}\text { Csp7a } \\
\text { Csp7b }\end{array}$ & $\begin{array}{l}-0.230 \\
(-0.62) \\
1.13 \\
(2.22)^{*}\end{array}$ & $\begin{array}{l}0.002 \\
(0.00) \\
-4.430 \\
(-0.49)\end{array}$ & $\begin{array}{l}0.695 \\
(0.92) \\
-0.719 \\
(-0.77)\end{array}$ & $\begin{array}{l}0.623 \\
(0.83) \\
-0.749 \\
(-0.86)\end{array}$ & $\begin{array}{l}0.143 \\
(0.19) \\
-0.749 \\
(-0.86)\end{array}$ & $\begin{array}{l}0.095 \\
(0.61) \\
/\end{array}$ \\
\hline $\begin{array}{l}\text { Laborer member of tontines } \\
\text { Female laborer member of tontines }\end{array}$ & $\begin{array}{l}\text { Csp8a } \\
\text { Csp8b }\end{array}$ & $\begin{array}{l}-0.433 \\
(-4.48)^{*} \\
-0.152 \\
(-2.16)^{*}\end{array}$ & $\begin{array}{l}-0.023 \\
(-0.12) \\
-0.132 \\
(-0.48)\end{array}$ & $\begin{array}{l}-0.606 \\
(-2.08)^{*} \\
0.017 \\
(0.04)\end{array}$ & $\begin{array}{l}-0.082 \\
(-0.45) \\
-0.282 \\
(-1.02)\end{array}$ & $\begin{array}{l}-0.151 \\
(-0.82) \\
-0.180 \\
(-0.076)\end{array}$ & $\begin{array}{l}-0.699 \\
(-2.76)^{*} \\
0.119 \\
(0.28)\end{array}$ \\
\hline
\end{tabular}

Source: Author's construction, ( ) student t tests $\quad *$ statistically significant at the 5\% level; Number of observations: 1989; Wald chi2 (24) = 548,29; Prob $>$ chi2 $=0,0000 ;$ Pseudo R2 = 0,5453 
The estimation results of probit models in order to capture the phenomenon of social learning, the role of social neighborhood and particularly the effects of peers in the process of adoption of internet technology are presented in table 6. The estimation strategy consisted simply of considering as endogenous variables the fact to have already used the internet alone or assisted (code V119 in the questionnaire), to have accessed the internet in the last three months (code V130 in the questionnaire), to become a counselor on the choice of internet access providers (code V129 in questionnaire), to have served as a counselor in the choice of a cybercafé (code 128 in questionnaire), and finally to have counseled on the choice of uses of the internet (code 127 in the questionnaire) or simply to have always accessed the internet no matter the place(code 131 in the questionnaire). Explanatory variables of the adoption and use of the internet have been defined by participation in tontines created in enterprises, high schools, primary schools and universities, in short to tontines of socioprofessional categories.

Interpreting the results let to the estimation of marginal effects which are presented in table 7. But, we can already note that the likelihood statistics, in particular the logarithms of pseudo likelihood ratio of the different models are all significant and therefore indicate that the explanatory power is acceptable. The marginal effects have the same level of significance as the estimated coefficients.

Table 7: Marginal effects estimation results

\begin{tabular}{|c|c|c|c|c|c|c|}
\hline variables & $\begin{array}{r}\mathrm{V} 119 \\
\Delta \mathrm{Y} / \mathrm{Y} \\
\end{array}$ & $\begin{array}{l}\mathrm{V} 130 \\
\Delta \mathrm{Y} / \mathrm{Y} \\
\end{array}$ & $\begin{array}{r}V 129 \\
\Delta \mathrm{Y} / \mathrm{Y} \\
\end{array}$ & $\begin{array}{r}\mathrm{V} 128 \\
\Delta \mathrm{Y} / \mathrm{Y} \\
\end{array}$ & $\begin{array}{r}\mathrm{V} 127 \\
\Delta \mathrm{Y} / \mathrm{Y} \\
\end{array}$ & $\begin{array}{l}V 131 \\
\Delta Y / Y \\
\end{array}$ \\
\hline $\begin{array}{l}\text { Csp1a } \\
\text { Csp1b }\end{array}$ & $\begin{array}{l}-0.811 \\
(-3.91)^{*} \\
0.392 \\
(1.36)\end{array}$ & $\begin{array}{l}-0.127 \\
(-0.67) \\
-0.505 \\
(-1.32)\end{array}$ & $\begin{array}{l}-2.99 \\
(-12.51) \\
/\end{array}$ & $\begin{array}{l}-0.0081 \\
(-0.02) \\
-0.150 \\
(-0.47)\end{array}$ & $\begin{array}{l}-0.319 \\
(-1.02) \\
0.0403 \\
(0.08)\end{array}$ & $\begin{array}{l}3.632 \\
(9.77) \\
/\end{array}$ \\
\hline $\begin{array}{l}\text { Csp2a } \\
\text { Csp2b }\end{array}$ & $\begin{array}{l}0.179 \\
(0.36) \\
0.451 \\
(0.99)\end{array}$ & $\begin{array}{l}4.69 \\
(16.63)^{*} \\
-3.671 \\
\left(-7.36^{*}\right)\end{array}$ & $\begin{array}{l}-3.952 \\
(-9.86)^{*} \\
3.518 \\
(12.16)^{*}\end{array}$ & $\begin{array}{l}0.117 \\
(0.26) \\
0.310 \\
(0.47)\end{array}$ & $\begin{array}{l}-0.237 \\
(-0.31) \\
0.153 \\
(0.27)\end{array}$ & $\begin{array}{l}0.663 \\
(0.53) \\
/\end{array}$ \\
\hline $\begin{array}{l}\text { Csp3a } \\
\text { Csp3b }\end{array}$ & $\begin{array}{l}-0.230 \\
(-6.41)^{*} \\
-0.815 \\
(-2.10)^{*}\end{array}$ & $\begin{array}{l}1 \\
1 \\
1\end{array}$ & $\begin{array}{l}0.309 \\
(3.28)^{*} \\
/\end{array}$ & $\begin{array}{l}0.027 \\
(0.14) \\
/\end{array}$ & $\begin{array}{l}0.177 \\
(2.09)^{*} \\
/\end{array}$ & $\begin{array}{l}0.941 \\
(0.68) \\
/\end{array}$ \\
\hline $\begin{array}{l}\text { Csp4a } \\
\text { Csp4b }\end{array}$ & $\begin{array}{l}-0.146 \\
(-1.15) \\
0.268 \\
(1.49)\end{array}$ & $\begin{array}{l}-0.107 \\
(-0.46) \\
-0.227 \\
(-1.00)\end{array}$ & $\begin{array}{l}-0.931 \\
(-0.42) \\
/\end{array}$ & $\begin{array}{l}-0.072 \\
(-0.67) \\
-0.385 \\
(-1.30)\end{array}$ & $\begin{array}{l}-0.198 \\
(-0.105) \\
0.395 \\
(1.05)\end{array}$ & $\begin{array}{l}-0.065 \\
(0.63) \\
0.103 \\
(0.31)\end{array}$ \\
\hline Csp5a & $\begin{array}{l}0.95 \\
(8.106)^{*}\end{array}$ & $\begin{array}{l}0.483 \\
(3.28)^{*}\end{array}$ & $\begin{array}{l}0.503 \\
(3.55)^{*}\end{array}$ & $\begin{array}{l}0.122 \\
(0.96)\end{array}$ & $\begin{array}{l}0.302 \\
(2.08)^{*}\end{array}$ & $\begin{array}{l}-0.502 \\
(1.70)\end{array}$ \\
\hline Csp5b & $\begin{array}{l}-0.228 \\
(-3.65)^{*}\end{array}$ & $\begin{array}{l}-0.145 \\
(-0.60)\end{array}$ & $\begin{array}{l}0.017 \\
(0.11)\end{array}$ & $\begin{array}{l}0.607 \\
(2.38)^{*}\end{array}$ & $\begin{array}{l}0.231 \\
(0.94)\end{array}$ & $\begin{array}{l}-0.305 \\
(-0.64)\end{array}$ \\
\hline Csp6a & $\begin{array}{l}0.609 \\
(5.01)^{*}\end{array}$ & $\begin{array}{l}0.192 \\
(0.91)\end{array}$ & $\begin{array}{l}0.071 \\
(0.25)\end{array}$ & $\begin{array}{l}-0.065 \\
(-0.31)\end{array}$ & $\begin{array}{l}0.309 \\
(1.63)\end{array}$ & $\begin{array}{l}0.045 \\
(0.39)\end{array}$ \\
\hline Csp6b & $\begin{array}{l}0.603 \\
(2.30)^{*}\end{array}$ & $\begin{array}{l}0.135 \\
(0.43)\end{array}$ & $\begin{array}{l}0.137 \\
(0.76)\end{array}$ & $\begin{array}{l}0.266 \\
(1.16)\end{array}$ & $\begin{array}{l}0.117 \\
(0.42)\end{array}$ & $\begin{array}{l}3.614 \\
(11.28)^{*}\end{array}$ \\
\hline $\begin{array}{l}\text { Csp7a } \\
\text { Csp7b }\end{array}$ & $\begin{array}{l}-0.113 \\
(-0.82) \\
1.03 \\
(2.32)^{*}\end{array}$ & $\begin{array}{l}0.001 \\
(0.00) \\
-3.130 \\
(-0.59)\end{array}$ & $\begin{array}{l}0.505 \\
(0.82) \\
-0.620 \\
(-0.78)\end{array}$ & $\begin{array}{l}0.425 \\
(0.82) \\
-0.639 \\
(-0.86)\end{array}$ & $\begin{array}{l}0.103 \\
(0.20) \\
-0.449 \\
(-0.85)\end{array}$ & $\begin{array}{l}0.065 \\
(0.52) \\
/\end{array}$ \\
\hline $\begin{array}{l}\text { Csp8a } \\
\text { Csp8b }\end{array}$ & $\begin{array}{l}-0.333 \\
(-4.48)^{*} \\
-0.111 \\
(-2.16)^{*}\end{array}$ & $\begin{array}{l}-0.016 \\
(-0.11) \\
-0.122 \\
(-0.48)\end{array}$ & $\begin{array}{l}-0.416 \\
(-2.08)^{*} \\
0.012 \\
(0.04)\end{array}$ & $\begin{array}{l}-0.062 \\
(-0.45) \\
-0.172 \\
(-1.03)\end{array}$ & $\begin{array}{l}-0.111 \\
(-0.83) \\
-0.171 \\
(-0.076)\end{array}$ & $\begin{array}{l}-0.429 \\
(-2.36)^{*} \\
0.119 \\
(0.22)\end{array}$ \\
\hline & $\begin{array}{l}\mathrm{Y}=\operatorname{Pr}(\mathrm{V} 119)= \\
0,3611105\end{array}$ & $\begin{array}{l}\mathrm{Y}=\operatorname{Pr}(\mathrm{V} 130)= \\
0,2212113\end{array}$ & $\begin{array}{l}\mathrm{Y}=\operatorname{Pr}(\mathrm{V} 129)= \\
0,2712153\end{array}$ & $\begin{array}{l}\mathrm{Y}=\operatorname{Pr}(\mathrm{V} 128)= \\
0,2319905\end{array}$ & $\begin{array}{l}\mathrm{Y}=\operatorname{Pr}(\mathrm{V} 127)= \\
0,2612133\end{array}$ & $\begin{array}{l}\mathrm{Y}=\operatorname{Pr}(\mathrm{V} 131)= \\
0,2412144\end{array}$ \\
\hline
\end{tabular}

Source: Author's construction, ( ) student t tests * statistically significant at the 5\% level; Number of observations: 1999; Wald chi2 (26) = 544, 30;

In a general manner, the fact to be a member of a tontine does not have a specific effect on the probability to use the internet alone or assisted (V119) or to have accessed internet no matter the place; it however increases the probability to be a counselor on the choice of an internet access provider (V 129), increases the probability to have accessed the internet during the last three months (V130) as well as to be a counselor on the choice of a cybercafé 
(V128) and on the uses of the internet (V127). The different contributions of households participating in at least one tontine in their socio-professional categories to these probabilities are very eloquent but with different significances. In fact, we systematically notice that social categories constituted by the unemployed (Cspla), farmers and craftsmen (Csp3a), traders and head of enterprises (Csp4a), Laborers (Csp8a) reduce this probability. This result however changes when we consider gender issues especially in socio-professional categories of the unemployed (Csplb), of traders and head of enterprises (Csp4b).

Meanwhile this probability increases in social categories made up of: female unemployed who are members of tontines, female students members of tontines, female traders and heads of enterprises members of at least one tontine, superior intellectual cadres members of tontines, intermediary professions, even women, who are members of tontines, female employees members of tontines, female superior intellectual cadres members of tontines. These last results refined those obtained in tontines without distinction of socio-professional categories- the ROSCAs: necessity of minimal computer training, necessity of belonging to a socio-professional category which can produce informational externalities.

\section{Conclusion}

By the end of this paper, it appears that in sub-Saharan Africa and Cameroon in particular, the tontine of ROSCAtype, which has as main objective the provision of rotating savings and credits constitute networks of physical meetings of members maintaining strong ties (Granovetter 2000) in a controlled social framework (Polagny 1977 Grannovetter 1985, 2000). These strong bonds as well as the social location of the conventional framework must be seen as the necessary and sufficient guarantee against all default risk due to the danger of information asymmetry against which weak network bonds (Granovetter 2000) that consecrated forces cannot preserve. Without being excluded, modern social values(education at the intermediary or high level, computer training, socio-professional category) which are also prerequisites to learning for the appropriation of internet technology and which condition behaviors of adoption does not form the base but is important only at the social categories where they are found. The results found in this study (the zero inflated count data models results in table 1) show that: though favorable to the learning of agricultural technologies and contraceptives, peer effects in ROSCA models have an uncertain role in the adoption of the Internet.

In practice, the tontine as a closed club, set in motion the social interactions that can treat the two questions raised by the adoption of any new technology: that linked to all types of costs implied by the new technology and that linked to the advantages and utility that it can offer. The first question leans on the analysis of the efforts and costs necessary for the learning and training in new practices but also on those of the absence of the perceived comparative advantages of the technology introduced (Davis 1989). Members of the social network off-line that is a tontine perceive it as a privileged support for the diffusion of signals in the form of informational externality and that enlightens opportunities which reveal the ex-ante benefits and reduces learning cost ceteris paribus. Being educated and having a huge social network of users of the technology around us (local externalities) and beyong (global externalities) reinforces the probability of individual adoption. The results of the probit models (table 6 and 7) showed that the tontine can serve as a framework if they are considered in occupational categories. Highlighting funding opportunities but also those of socialization and sharing, where peer effects are likely to play offline and strengthen the inter-personal trust (Etang Fieldding and Knowles, 2007) the second question shows that participating in a tontine increases the individual social capital that affected the practices of the Internet (Pénard, Suire, 2011). This is all the more plausible that dissocializing Internet has been studied and validated in the United States and Europe at the beginning of the dynamics of diffusion. But the results presented here show that peer effects play positively on learning and technology appropriation that underlie the adoption and uses of the Internet not in tontine of ROSCA-type, but in the tontine envisaged in professional categories according to their propensity to use modern values for jobs.

JEL: I21, J24, O12, O31

\section{References}

[1] Aghion, P, Howitt P, (1998) Endogenous Growth Theory. Cambridge, MIT Press.

[2] Bandiera, O., Rasul I., (2006), Social networks and technology adoption in Northern Mozambique. The economic journal, 116 (514). pp. 869-902

[3] Barro R. J, Sala-i-Martin X, (1994), "Quality Improvements in Models of Growth," NBER Working Papers 4610, National Bureau of Economic Research, Inc.

[4] Brandner, L, Strauss, M, (1959) Congruence Versus Profitability in the Diffusion of Hybrid Sorghum" Rural Sociology, 24, pp $381\{383$.

[5] Conley T. G., Udry C. R.. 2010. "Learning about a New Technology: Pineapple in Ghana.The American Economic Review Vol. 100, No. 1 pp. 35-69

[6] Davis F.D (1989) "Perceived Usefulness, Perceived Ease of USE, and User Acceptance of Information Technology". MIS Quarterly 13(3) pp319-339.

[7] Etang A, Fielding D, Knowles S, (2007), Survey Trust, Experimental Trust and ROSCA, University of Otago, Economics Discussion Papers, No. 0713

[8] Feder, G, Slade R, (1984), The Acquisition of Information 
and the Adoption of New Technology, American Journal of Agricultural Economics, Vol. 66, No. 3, pp. 312-320

[9] Feder.G, Just R, E, Zilberman, D, (1985) “Adoption of Agricultural Innovations in Developing Countries: A Survey", Economic Development and Cultural Change 33: pp. 255-298.

[10] Foster.A, Rosenzweig M, (1995) "Learning by Doing and Learning from Others: Human Capital and Technical Change in Agriculture", Journal of Political Economy 103: pp. 1176-1209.

[11] Giné X, Klonner S, (2005), Credit Constraints as a Barrier to Technology Adoption by the Poor, Lessons from SouthIndian Small-Scale Fishery, World Bank Policy Research Working Paper 3665.

[12] Glaeser E, Kallal H, Scheinkman J, Shleifer A, (1992). "Growth in Cities." Journal of Political Economy 100 (6): pp 1126-1152.

[13] Granovetter M, S, (1985) "Economic Action and Social Structure: The Problem of Embeddedness", American Journal of Sociology 91: pp. 481-510.

[14] Granovetter M., (2000), Le marché autrement, Paris, Desclée de Brouwer, coll. "Sociologie économique", 239 pages, trad. de l'américain par Isabelle This-Saint Jean, 2000

[15] Griliches, Z, (1957), Hybrid Corn: An Exploration in the Economics of Technological Change,", Econometrica", 25 (4), pp 501-522.

[16] Havens, E, A, Rogers E, M, (1961), Adoption of Hybrid Corn: Profitability and the Interaction Effect," Rural Sociology, 26 (4), pp 409-414.

[17] Isham J, 2002. "The Effect of Social Capital on Fertiliser Adoption: Evidence from Rural Tanzania," Journal of African Economies, vol. 11(1), pp 39-60.

[18] Jacobs, Jane. (1969). The Economy of Cities. New York: Vintage

[19] Kremer M, Miguel, E, (2004b) Networks, Social Learning, and Technology Adoption:

[20] The Case of Deworming Drugs in Kenya, mimeo Harvard University.

[21] Manski C., F., (1993). .Identification of endogenous social effects: the reflection problem, Review of Economic Studies 60 (3): pp $531-542$

[22] Marshall A., (1890), Principles of Economics. London: Macmillan.

[23] Lucas R. E. J., (1988), "On the Mechanics of Economic Development.” Journal of Monetary Economics. 22: pp 3-42.
[24] Mcfadden D, and Train K, (1996) “Consumers' Evaluation of New Products: Learning from Self and Others", Journal of Political Economy 104: pp. 683-703.

[25] Mukoko B, (2012) Determinants of Computer and Internet Adoption and Use in Cameroon, African Review of Economics and Finance, Vol. 3, No.2, pp 96-128

[26] Munshi K, (2004) "Social Learning in a Heterogeneous Population: Social Learning in the Indian Green Revolution", Journal of Development Economics 73: pp. $185-213$

[27] Oster E, Thornton R, (2009), Determinants of Technology Adoption: Private Value and Peer Effects in Menstrual Cup Take-Up, WP n ${ }^{\circ} 14828$.

[28] Penard T, Poussing N, (2006), "Usage de l'Internet et investissement en capital social," Discussion Papers (REL Recherches Economiques de Louvain) 2006043.

[29] Pénard T, Poussing N, Suire R, (2011) "Does the Internet make people happier ?," Economics Working Paper Archive (University of Rennes 1 \& University of Caen) 201106.

[30] Pilon M, Locoh T, Vignikin E, Vimard P, (sous la dir ; de), (1997), Ménages et Familles en Afrique, Paris, CEPED, ENSAE, RSTORM, 402p.

[31] Porter, Michael E., (1990), The Competitive Advantage of Nations. New York: Free Press.

[32] Rogers E. M, (1995), Diffusion of Innovations (4th edition), New York: The Free Press.

[33] Rosenzweig, M. R., (2010), "Microeconomic Approaches to Development: Schooling, Learning, and Growth," Working Papers 79, Yale University, Department of Economics.

[34] Rauch J. E., (1993), "Productivity Gains from Geographic Concentration of Human Capital: Evidence from Cities." Journal of Urban Economics 34: pp 380-400.

[35] Romer, P, (1986), "Increasing Returns and Long-Run Growth" Journal of Political Economy.94 (5): pp 1002-1037

[36] Sacerdote B, (2001) "Peer Effects with Random Assignment: Results for Dartmouth Roommates", Quarterly Journal of Economics 116: pp 681-704.

[37] Tamokwe Piaptie G.B, (2012), Complementarity or substitutability between the different modes of internet access: a property rights-based analysis on cybercafés offerings with data from Cameroon, The Electronic Journal on Information Systems in Developing Countries (EJISDC) 55,5, pp 1-14

[38] Udry.C, (1994) "Risk and Insurance in a Rural Credit Market: An Empirical Investigation in Northern Nigeria", Review of Economic Studies 61: pp. 495-526. 